\title{
Th2-high asthma: a heterogeneous asthma population?
}

\author{
Seys Sven ${ }^{1 *}$, Hans Scheers ${ }^{2}$, Gudrun Marijsse ${ }^{1}$, Ellen Dilissen ${ }^{1}$, Annelies Van Den Bergh ${ }^{3}$, Pieter Goeminne ${ }^{3}$, \\ Paul Van den Brande ${ }^{3}$, Jan Ceuppens ${ }^{1}$, Lieven Dupont ${ }^{3}$, Dominique Bullens ${ }^{4}$
}

From 2nd International Severe Asthma Forum (ISAF)

Athens, Greece. 13-15 November 2014

\section{Background}

Airway inflammation in asthma can be subdivided in Th2-high and Th2-low.

\section{Objective}

To identify unique patient clusters with a specific airway cytokine expression profile in an unselected population with asthma.

\section{Methods}

Induced sputum and clinical records were analysed from 208 asthmatics and 80 healthy individuals. Cytokinehigh patients had cytokine mRNA levels above the $90^{\text {th }}$ percentile value in controls. Unsupervised hierarchical clustering was used to determine unique cytokine-based patient clusters.

\section{Results}

Cubic Clustering Criterion, pseudo $\mathrm{F}$ and $\mathrm{t}^{2}$ statistics revealed a two- and a six-cluster model. The first cluster $(n=23)$ was found in both models and consists of patients who present with an "IL-5-high and IL-17F-high" profile. Patients with an "IL-4- or IL-13-high" profile did not cluster in one single group. In the six-cluster model, the "IL-17F-low" group was divided into 5 separate clusters: "IL-5-high" profile $(\mathrm{n}=7)$, "IFN- $\gamma$-high" profile $(\mathrm{n}=15)$, "IL-6- and/or TNF-high" profile $(\mathrm{n}=15)$, "IL-22-high" profile $(\mathrm{n}=15)$ and those patients that were low for all preceding cytokines $(\mathrm{n}=130$; cluster 6$)$. "IL-17F- and IL-5-high" patients had significantly lower $\mathrm{FEV}_{1}$ and higher sputum neutrophils. Patients that were only "IL-4or IL-13-high" (cluster 6) had highest $\mathrm{F}_{\mathrm{E}} \mathrm{NO}$ levels and sputum eosinophils.

${ }^{1}$ University of Leuven, Clinical Immunology, Leuven, Belgium

Full list of author information is available at the end of the article

\section{Conclusion}

Th2-high asthma can be subdivided in patients with "IL-5-high and IL-17F-high" asthma and those with "IL4- or IL-13-high" asthma. The inflammatory pattern is different between both groups. The former group is characterized by mixed granulocytic airway inflammation whereas the latter group consists of patients with eosinophilic airway inflammation.

\section{Authors' details}

${ }^{1}$ University of Leuven, Clinical Immunology, Leuven, Belgium. ${ }^{2}$ University of Leuven, Pneumology, Leuven, Belgium. ${ }^{3}$ University Hospitals Leuven, Pneumology, Leuven, Belgium. ${ }^{4}$ University of Leuven, Pediatric Immunology, Leuven, Belgium.

Published: 23 March 2015

\section{doi:10.1186/2045-7022-5-S2-O1}

Cite this article as: Sven et al:: Th2-high asthma: a heterogeneous asthma population? Clinical and Translational Allergy 2015 5(Suppl 2):01.

Submit your next manuscript to BioMed Central and take full advantage of:

- Convenient online submission

- Thorough peer review

- No space constraints or color figure charges

- Immediate publication on acceptance

- Inclusion in PubMed, CAS, Scopus and Google Scholar

- Research which is freely available for redistribution

Submit your manuscript at www.biomedcentral.com/submit
() Biomed Central 